Dikirim: 15 September 2016 Diterbitkan: 1 April 2017

\section{Kadar timbal dalam darah pada petugas stasiun pengisian bahan bakar}

\section{Blood lead level among workers in gas station}

Brian Klopfleisch ${ }^{1}$, Adi Heru Sutomo ${ }^{2}$, Susi Iravati ${ }^{3}$

\begin{abstract}
Purpose: This study aimed to determine the effect of lead levels with oxidative stress in gas station officers in the Sleman region through measurement of malondialdehyde levels (MDA). Methods: This research was an observational analytic study involving 43 gas station workers. Blood lead levels were measured by atomic absorption spectrophotometer (SSA) methods. Serum MDA levels were measured by the TBRs methods. Results: This study found the average lead concentration in blood of SPBU officers was $62.174 \mu \mathrm{g} / \mathrm{L}$ while the serum MDA level obtained mean $5.86 \mu \mathrm{mol} / \mathrm{L}$. The result of statistical tests using Pearson correlation showed that there was a significant influence between blood lead level and MDA level $(p=0.000)$ with very strong correlation strength $(r=0.8432)$. Conclusion: Gas station officers are susceptible to exposure to lead, so it is necessary to prevent the deterioration of health conditions by the use of personal protective equipment (PPE), healthy lifestyle, and routine medical check-ups.
\end{abstract}

Keywords: blood lead levels; malondialdehid; gas station workers

\footnotetext{
${ }^{1}$ Departemen Perilaku Kesehatan, Lingkungan dan Kedokteran Sosial, Fakultas Kedokteran, Universitas Gadjah Mada (Email: b.klopfleisch@gmail.com)

${ }^{2}$ Departemen Kedokteran Keluarga, Komunitas dan Bioetika, Fakultas Kedokteran, Universitas Gadjah Mada

${ }^{3}$ Departemen Mikrobiologi, Fakultas Kedokteran, Universitas Gadjah Mada
} 


\section{PENDAHULUAN}

Logam berat memiliki efek berbahaya bagi kesehatan manusia. Timbal, merkuri dan cadmium merupakan beberapa contoh logam berat yang banyak tersebar di lingkungan dan bila terakumulasi di dalam tubuh dapat berbahaya bagi kesehatan (1). Timbal merupakan salah satu jenis logam berat yang secara alamiah terdapat di alam. Keberadaan timbal di alam meningkat seiring dengan aktivitas manusia, seperti pertambangan, peleburan, penggunaan dalam bahan bakar minyak dan pemakaian timbal untuk kebutuhan komersial (2). Daftar Agency for Toxic Substances and Disease Registry (ARTS) menempatkan timbal (Pb) urutan kedua setelah arsen sebagai salah satu logam berat yang paling beracun dilihat dari kombinasi frekuensi keberadaan di lingkungan, toksisitas dan potensi terpapar manusia (3).

Timbal dapat menyebabkan pencemaran udara akibat gas emisi kendaraan bermotor. Hal ini telah menjadi permasalahan kesehatan masyarakat secara global, terutama bagi negara berkembang, seperti Afrika, Asia dan Amerika Latin yang masih menggunakan bahan bakar kendaraan dengan timbal. Pencemaran udara di Indonesia sekitar 85\% berasal dari gas emisi kendaraan bermotor dan berpengaruh terhadap kadar timbal dalam darah seseorang yang beraktivitas tinggi di jalanan. Kelompok pekerja yang berisiko tinggi terhadap paparan polutan timbal di udara seperti polisi lalu lintas, pedagang kaki lima, pengemis dan petugas Stasiun Pengisian Bahan Bakar (SPBU) $(4,5)$.

Petugas Stasiun Pengisian Bahan Bakar untuk Umum (SPBU) sebagai salah satu kelompok yang mempunyai risiko tinggi untuk terpapar timbal secara langsung. Paparan timbal dapat berasal dari emisi kendaraan yang datang maupun uap yang berasal dari bensin saat pengisian (6). Kandungan timbal dalam tubuh dapat dideteksi melalui darah, rambut dan urine (7). Beberapa penelitian melaporkan kadar timbal pada pekerja SPBU baik pria maupun wanita melebihi batas kadar aman dan menimbulkan berbagai gangguan kesehatan seperti hipertensi, rasa mual, kelelahan, susah bernapas, dan gusi berdarah (8-10).

Paparan timbal yang masuk melalui udara sekitar $30-40 \%$ akan diabsorbsi ke dalam darah. Di dalam darah timbal akan menghambat sintesis heme melalui pengikatan gugus thiol pada enzim Aminoluvucinic Acid Dehydrase. Timbal juga akan merusak enzim-enzim antioksidan seperti Superoxide dismutase (SOD), Catalase (CAT), dan Gluthation Peroxidase (GPx) yang mengakibatkan pembentukan senyawa radikal bebas berupa Reactive Oxygen Species (ROS) tidak terkontrol. Ketidakseimbangan antara banyak radikal bebas dengan antioksidan menyebabkan stres oksidatif terjadi yang berkaitan dengan kerusakan membran sel, DNA, RNA dan kerusakan pada sel otak $(11,12)$.

Malondialdehid (MDA) sering digunakan di banyak laboratorium sebagai indikator untuk mengetahui tingkat kerusakan akibat stres oksidatif. Malondialdehid adalah salah satu aldehida utama, berasal dari peroksidasi lipid berkarbon tiga yang reaktif di dalam membran sel dan membentuk ikatan kompleks dengan unsur lainnya di dalam jaringan. Semakin tinggi stres oksidatif yang terjadi di dalam sel-sel tubuh memberikan dampak yang sama dengan meningkatnya nilai MDA $(13,14)$. Paparan logam berat $(\mathrm{Cu}, \mathrm{Zn}, \mathrm{Cd}, \mathrm{Pb}$, As) dilaporkan menyebabkan peningkatan kadar MDA (15). Berdasarkan paparan di atas maka perlu penelitian yang mengukur pengaruh kadar timbal dengan stres oksidatif pada petugas SPBU.

\section{METODE}

Penelitian observasional analitik ini menggunakan desain cross-sectional. Populasi penelitian sebanyak 70 orang petugas SPBU di 3 tempat: Jln. Magelang, Jln Adji Sucipto dan Jln. Monjali yang berada di daerah Sleman. Besar sampel yang penelitian ini sebanyak 43 orang yang sesuai dengan kriteria inklusi dan eksklusi. Kriteria inklusi sampel adalah berusia 17-45 tahun, masa kerja $>1$ tahun, dan aktif bekerja 2 bulan terakhir. Kriteria eksklusi sampel adalah pekerja SPBU yang memiliki penyakit kronis berdasarkan anamnesis kuesioner, dan sedang mengonsumsi obat-obatan.

Pemeriksaan kadar timbal dalam darah di ukur di Laboratorium Balai Besar Teknik Kesehatan dan Pengendalian Penyakit Yogyakarta dengan metode Spetrofotometer Serapan Atom (SSA) sedangkan pemeriksaan plasma malondialdehid di ukur di Laboratorium PAU UGM menggunakan metode TBRs.

Analisis data yang digunakan adalah analisis univariat, bivariat dan multivariat. Analisis univariat digunakan untuk menganalisis data secara deskriptif mengenai karakteristik masing-masing variabel yang diteliti. Analisis bivariat digunakan untuk mengetahui hubungan antara variabel luar berupa usia, IMT, dan masa kerja, dengan kadar malondialdehid dalam darah diuji menggunakan uji statistik one way ANOVA. Hubungan variabel kebiasaan merokok dan penggunaan APD dengan kadar malondialdehid diuji menggunakan uji statistik independent t-test. Uji pearson correlation untuk melihat kekuatan hubungan antara variabel yang signifikan dengan kadar MDA. 
Analisis multivariat digunakan untuk mengetahui pengaruh satu variabel dengan mempertimbangkan variabel lainnya. Analisis multivariat yang digunakan adalah analisis multivariat regresi linier.

\section{HASIL}

Tabel 1 menunjukkan distribusi subjek penelitian. Karakteristik subjek penelitian berusia 20-45 tahun, jumlah terbanyak berusia 26-30 tahun adalah 15 orang $(34,88 \%)$ sedangkan jumlah yang paling sedikit berusia 41-45 tahun yakni 4 orang (9,30\%). Berdasarkan jenis kelamin sebagian besar subjek penelitian adalah laki laki, sebanyak 35 orang (81,4\%), dan perempuan hanya 8 orang $(18,6 \%)$.

Riwayat merokok pada subjek penelitian, sebanyak 20 orang (46,51\%) memiliki kebiasaan merokok sedangkan 23 orang lainnya tidak merokok (53,49\%). Berdasarkan kebiasaan konsumsi alkohol, semua subjek penelitian (100\%) tidak memiliki kebiasaan minum minuman beralkohol. Berdasarkan kategori Indeks Masa Tubuh (IMT), sebagian besar subjek penelitian IMT normal yakni 29 orang $(67,44 \%)$.

Paling banyak subjek penelitian telah bekerja 1-5 tahun sebanyak 18 orang (41,86\%) dan paling sedikit 6 orang telah bekerja 15-20 tahun. Subjek penelitian yang rutin menggunakan APD sebanyak 9 orang $(13,95 \%)$ sedangkan sebanyak 34 orang $(79,7 \%)$ tidak pernah menggunakan APD.

Tabel 1. Karakteristik subjek penelitian di SPBU Jln. Monjali, SPBU Jln. Magelang, SPBU Jln.Adjisucipto

\begin{tabular}{|c|c|}
\hline Karakteristik & $\%(n=43)$ \\
\hline \multicolumn{2}{|l|}{ Usia (tahun) } \\
\hline $20-25(n=14)$ & 32,56 \\
\hline $26-30(n=15)$ & 34,88 \\
\hline $31-35(n=5)$ & 11,63 \\
\hline $36-40(n=5)$ & 11,63 \\
\hline $41-45(n=4)$ & 9,30 \\
\hline \multicolumn{2}{|l|}{ Jenis Kelamin } \\
\hline Laki-laki (n=35) & 81,4 \\
\hline Perempuan $(\mathrm{n}=8)$ & 18,6 \\
\hline \multicolumn{2}{|c|}{ Kebiasaan Merokok } \\
\hline Ya $(n=20)$ & 46,51 \\
\hline Tidak $(n=23)$ & 53,49 \\
\hline \multicolumn{2}{|c|}{ Kebiasaan Minum Alkohol } \\
\hline $\mathrm{Ya}$ & 0 \\
\hline Tidak $(n=43)$ & 100 \\
\hline \multicolumn{2}{|l|}{ IMT } \\
\hline Kurus $(n=8)$ & 18,6 \\
\hline Normal $(n=43)$ & 67,44 \\
\hline Gemuk $(n=6)$ & 13,95 \\
\hline \multicolumn{2}{|c|}{ Masa kerja (tahun) } \\
\hline $1-5(n=18)$ & 41,86 \\
\hline $6-10(n=10)$ & 23,26 \\
\hline $11-15(n-9)$ & 20,93 \\
\hline $16-20(n=6)$ & 13,95 \\
\hline \multicolumn{2}{|l|}{ Penggunaan APD } \\
\hline $\mathrm{Ya}(\mathrm{n}=9)$ & 20,93 \\
\hline Tidak $(n=34)$ & 79,07 \\
\hline
\end{tabular}

Tabel 2 menunjukkan bahwa rerata kadar timbal dalam darah pada seluruh subjek penelitian adalah 62,174 $\mu \mathrm{g} / \mathrm{L}$ dengan standar deviasi 23,602. Kadar timbal terendah $16,707 \mu \mathrm{g} / \mathrm{L}$ dan tertinggi adalah $118,503 \mu \mathrm{g} / \mathrm{L}$. Rerata kadar MDA 5,869 $\mu \mathrm{g} / \mathrm{L}$ dengan standar deviasi 1,232. Kadar MDA terendah adalah 3,53 $\mu \mathrm{g} / \mathrm{L}$ dan tertinggi adalah 7,97 $\mu \mathrm{g} / \mathrm{L}$.

Tabel 2. Rerata kadar timbal dan kadar malondialdehid dalam darah petugas SPBU

\begin{tabular}{lccc}
\hline \multicolumn{1}{c}{ Variabel } & Mean \pm SD & Min & Max \\
\hline Kadar Timbal & $62,174 \pm 23,602$ & 16,707 & 118,503 \\
Kadar & $5,869 \pm 1,2329$ & 3,53 & 7,97 \\
Malondialdehid & & & \\
\hline
\end{tabular}

Tabel 3. kadar timbal dalam darah dibagi dalam 2 kelompok yaitu kadar timbal $\geq 30 \mu \mathrm{g} / \mathrm{L}$ dikategorikan tinggi dan kadar timbal $<30 \mu \mathrm{g} / \mathrm{L}$ dikategorikan normal. Hal ini berdasarkan kriteria American Conference of Governmental Industrial Hygienists (ACGHI) bahwa klasifikasi kadar timbal darah normal apabila $<30 \mu \mathrm{g} / \mathrm{L} 16$.

Tabel 3. Analisis hubungan antara kadar timbal dengan kadar Malondialdehid darah petugas di SPBU

\begin{tabular}{lcc}
\hline \multicolumn{1}{c}{ Variabel } & $\begin{array}{l}\text { Kadar MDA } \\
\text { (Mean } \pm \text { SD) }\end{array}$ & P \\
\hline Kadar Timbal & & \\
Tinggi & $6,08 \pm 0,1820$ & 0,0009 \\
Rendah & $4,23 \pm 0,3181$ & \\
\hline
\end{tabular}

Gambar 1 menunjukkan korelasi antara kadar timbal dan kadar malondialdehid. Hasil uji Pearson correlation menunjukkan bahwa terdapat hubungan yang signifikan antara kadar timbal dan kadar malondialdehid, dengan nilai $\mathrm{p}=0,0000$. Nilai $\mathrm{r}=$ 0,8432 menunjukkan kekuatan hubungan dalam kategori sangat kuat. .

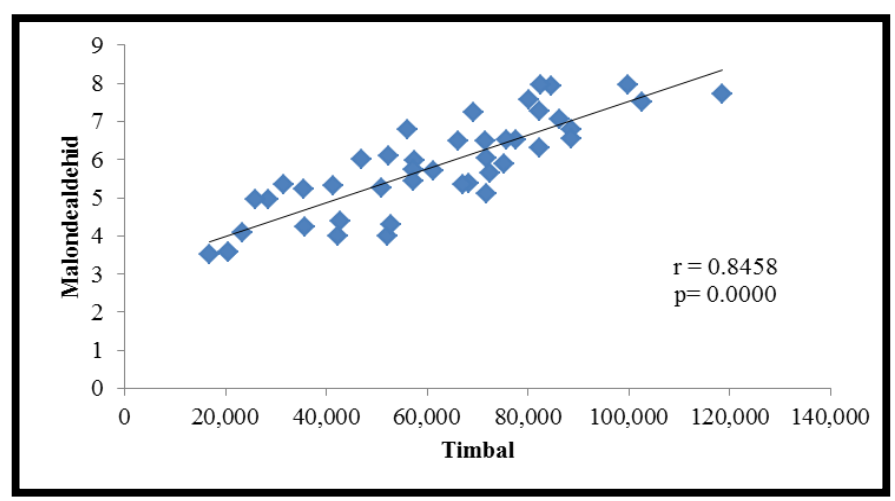

Gambar 1. Uji korelasi hubungan antara kadar timbal dengan kadar MDA 
Tabel 4 menunjukkan terdapat hubungan yang signifikan antara usia dan masa kerja dengan kadar malondialdehid petugas SPBU. Variabel merokok, IMT, dan penggunaan APD tidak berhubungan secara signifikan dengan kadar malondialdehid petugas SPBU.

Tabel 4. Hubungan variabel luar dengan kadar Malondialdehid dalam darah petugas SPBU

\begin{tabular}{lrc}
\hline \multicolumn{1}{c}{ Karakteristik } & $\begin{array}{c}\text { Malondialdehid } \\
\text { (Mean } \pm \text { SD) }\end{array}$ & $\boldsymbol{p}$ \\
\hline Usia & $4.6957 \pm 0.774$ & \\
20 -25 tahun & $6.284 \pm 1.015$ & \\
$26-30$ tahun & $6.632 \pm 1.133$ & $0.0000^{*}$ \\
$31-35$ tahun & $7.008 \pm 0.701$ & \\
36-40 tahun & $6.050 \pm 1.020$ & \\
41-45 tahun & & \\
Kebiasaan Merokok & $5.891 \pm 1.2676$ & \\
Ya & $5.851 \pm 1.2302$ & 0.9157 \\
Tidak pernah & & \\
IMT & $6.0287 \pm 1.287$ & \\
Kurus & $5.882 \pm 1.253$ & 0.8123 \\
Normal & $5.595 \pm 0.981$ & \\
Gemuk & & \\
Masa kerja & $4.9205 \pm 0.9675$ & \\
1-5 tahun & $6.2029 \pm 0.8208$ & \\
6-10 tahun & $7.125 \pm 0.6828$ & $0.0000^{*}$ \\
16-15 tahun & $6.278 \pm 1.059$ & \\
Penggunaan APD & & \\
Ya & $5.597 \pm 0.626$ & \\
Tidak pernah & $5.941 \pm 1.346$ & 0.4634 \\
\hline Keterangan $* *$ signifikan $(\mathrm{p}<0,05)$ &
\end{tabular}

Tabel 5 menunjukkan hasil uji regresi linier. Variabel yang berhubungan dengan kadar malondialdehid adalah kadar timbal dalam darah. Persamaan regresi yang diperoleh adalah Kadar MDA = $3,1605+0,000043 *$ kadar timbal.

Persamaan tersebut dapat digunakan untuk memprediksi nilai kadar MDA dengan mempertimbangkan kadar timbal, misalnya kadar timbal seseorang sebesar 10,000 $\mu \mathrm{g} / \mathrm{L}$ maka kadar MDA diprediksi sebesar 3,590 $\mu \mathrm{mol} / \mathrm{L}$.

Nilai $\mathrm{R}^{2} \quad 0,696$ memberikan arti kadar timbal berkontribusi sebesar 69,6\% terhadap kadar malondialdehid. Masih ada faktor lain yang memengaruhi kadar MDA sebesar 30,4\% seperti antioksidan, logam transisi lain yang berasal dari bahan bakar maupun gas-gas polutan yang berasal dari sisa pembakaran kendaraan bermotor.

Tabel 5. Uji regresi linier

\begin{tabular}{llcc}
\hline & \multicolumn{3}{c}{ Malondialdehid } \\
\cline { 2 - 4 } & Koefisien & SE & $\begin{array}{l}\text { Koefisien } \\
\text { Korelasi }\end{array}$ \\
\hline Kadar timbal & 0,000043 & $6,59 \mathrm{e}-06$ & $0,8342^{*}$ \\
Usia & 0,000046 & 0,0340 & 0,5266 \\
Masa kerja & $-0,0375$ & 0,0421 & 0,5481 \\
\hline
\end{tabular}

Keterangan: *signifikansi $=\mathrm{p}<0,05$

$\mathrm{R}^{2}=0.696$

konstanta $=3,1605$

\section{BAHASAN}

Timbal di dalam tubuh akan memengaruhi jalur sintesis heme, dengan cara menghambat heme, sintesis haemoglobin, mengubah morfologi sel darah merah dan memengaruhi kelangsungan hidup sel darah merah. Dalam jalur sintesis heme enzim Aminolevulinic acid dehydratase (ALAD) adalah salah satu enzim yang paling rentan terhadap efek toksik timbal. Beberapa penelitian telah menunjukkan kadar timbal yang rendah sekalipun ( sekitar $15 \mu \mathrm{g} / \mathrm{L}$ ) sudah dapat menghambat aktivitas enzim ALAD (16).

Hasil penelitian ini menunjukkan terdapat hubungan yang signifikan antara kadar timbal dengan kadar MDA dengan kekuatan hubungan sangat kuat $(r=0,8432)$. Hal ini berarti korelasi antara kadar timbal dengan kadar MDA baik secara klinis maupun secara statistik bermakna. Penelitian lain menunjukkan hubungan yang signifikan antara kadar timbal dengan kadar MDA (17).

Paparan radikal bebas yang berasal dari luar seperti usia dan masa kerja berdasarkan hasil penelitian ini menunjukkan terdapat pengaruh terhadap kadar MDA, namun pengaruh tersebut tidak lebih kuat dibanding kadar timbal berdasarkan uji statistik. Masa kerja pada penelitian ini dikaitkan dengan akumulasi dari paparan timbal, sehingga semakin lama masa kerja, semakin tinggi paparan timbal. Hal ini menjelaskan hubungan tidak langsung antara banyak paparan timbal dengan peningkatan kadar MDA.

Pengaruh lain berasal dari usia. Kadar MDA pada penelitian ini berpola yang sama dengan usia, bahwa semakin tinggi usia maka kadar MDA juga semakin tinggi, sejalan dengan penelitian yang membandingkan kadar MDA orang sehat pada kelompok usia muda dan lanjut usia. Hasil penelitian tersebut adalah kadar plasma MDA pada kelompok usia lanjut lebih tinggi dibandingankan dengan kelompok usia muda (18).

Penuaan merupakan proses kompleks dan multifaktorial yang secara alamiah terjadi dalam tubuh manusia dan secara bertahap menyebabkan penurunan beberapa fungsi tubuh untuk pertahanan maupun kesuburan. Proses penuaan juga sering dikaitkan dengan beberapa penyakit degeneratif pada usia lanjut. Penyebab penyakit degeneratif pada usia lanjut adalah beberapa kondisi seperti stres oksidatif akibat ketidakseimbangan antara radikal bebas yang terbentuk dari proses penuaan dengan kapasitas antioksidan dari dalam tubuh serta asupan dari luar, inflamasi kronik noninfeksisus akibat peningkatan produksi adipokin dan sitokin, perubahan pada 
metabolisme asam lemak termasuk peningkatan pelepasan asam lemak bebas ke plasma sehingga dapat menginduksi resistensi insulin, serta akumulasi berbagai produk akhir metabolime yang dapat mengganggu fungsi sel normal seperti Advance Glycation end Product (AGE) (19). Paparan radikal bebas lain yang berasal dari luar meliputi kebiasaan merokok, kebiasaan mengonsumsi alkohol, IMT yang secara langsung berpengaruh terhadap kadar MDA berdasarkan teori namun pada penelitian ini tidak memberikan pengaruh yang signifikan terhadap kadar MDA .

Satu batang rokok yang dibakar akan menghasilkan kira-kira $92 \%$ gas dan $8 \%$ partikel padat yang berupa aerosol cair dan partikel tar padat. Asap rokok mengandung ribuan komponen kimia dalam bentuk gas, yang bersifat spesies reaktif seperti oksida nitrogen (NO) (12). Pada penelitian ini menunjukkan tidak ada hubungan antara merokok dengan kadar MDA. Penelitian lain menunjukkan tidak ada hubungan antara kebiasaan merokok dengan kadar MDA pada pekerja petugas parkir swalayan. Hal ini tidak sejalan dengan penelitian yang membandingkan kadar MDA perokok dengan yang tidak merokok menunjukkan bahwa merokok menjadi prediktor yang bermakna dalam meningkatkan stres oksidatif setelah mengendalikan prediktor lainnya seperti profil lipid, IMT, jenis kelamin dan umur, serta menunjukkan bahwa orang yang merokok memiliki peluang 2,8 kali lebih tinggi meningkatkan kadar MDA $(20,21)$.

Indeks Masa Tubuh merupakan salah satu faktor yang juga dapat memengaruhi kadar MDA. Indeks Masa Tubuh memberikan ukuran numerik sederhana dari orang "kegemukan" atau "kurus" yang memungkinkan untuk membahas masalah yang lebih objektif mengenai kelebihan dan kekurangan berat badan. Kelebihan berat badan sering dikaitkan dengan berbagai penyakit, terutama penyakit kardiovaskular ataupun diabetes melitus, sementara orang yang kurus sering dikaitkan dengan kurangnya nutrisi yang masuk ke dalam tubuh yang berhubungan dengan kecukupan antioksidan di dalam tubuh (22).

Hasil penelitian ini menunjukkan bahwa IMT tidak berpengaruh terhadap kadar MDA dan sejalan dengan penelitian Khajehnasiri yang menunjukkan kadar MDA dengan IMT pada kelompok pekerja shift tidak ada hubungan yang signifikan (all $p$-value $>0.05$ ), ini dikarenakan rata-rata IMT pekerja 24,92 yang mana masih kategori normal. Berbeda dengan penelitian Highasi menunjukkan peningkatan kadar MDA pada orang dengan kategori underweight dan overweight dibandingankan dengan yang IMT normal. Sejalan dengan penelitian Yesilbursha et al yang menunjukkan peningkatan kadar MDA pada orang dengan kategori overweight (23-25).

Tubuh memiliki suatu sistem pertahanan untuk menangkal paparan radikal bebas yang disebut dengan sistem pertahanan antioksidan yang diperankan oleh berbagai enzim antioksidan dalam tubuh seperti Glutathion peroksidase (GPx), Superoksida dismutase (SOD), Katalase dan beberapa enzim lain. Selain berasal dari dalam tubuh, antoksidan juga dapat diperoleh dari luar misalnya konsumsi beberapa makanan tertentu yang mengandung antioksidan seperti vitamin C maupun vitamin E. Asupan makan yang bergizi yang kaya akan vitamin dapat mencegah pembentukan peroksidasi lipid di dalam tubuh. Penelitian Atef menunjukkan vitamin E dapat melindungi tubuh terhadap paparan timbal sehingga mencegah stres oksidatif hingga mencegah penurunan fungsi ginjal. Penerapan gaya hidup sehat seperti mengurangi kebiasaan merokok dan konsumsi alkohol juga turut berperan dalam mengurangi sumber paparan radikal bebas dari luar (26).

Upaya lain yang dapat dilakukan untuk mengurangi paparan radikal bebas khususnya yang berasal dari logam berat seperti timbal terutama bagi para pekerja seperti di SPBU adalah dengan penggunaan alat pelindung diri (APD) selama bekerja, seperti penggunaan masker. Dengan penggunaan APD yang tepat dapat meningkatkan nilai keselamatan dan kesehatan selama bekerja.

\section{SIMPULAN}

Kadar timbal dan kadar malondialdehid dalam darah petugas di SPBU Jln. Monjali, SPBU Jln. Magelang dan SPBU Jln.Adjisucipto sudah melebihi batas normal dengan rerata kadar timbal dalam darah petugas SPBU sebesar 62,174 $\mu \mathrm{g} / \mathrm{L}$ dan kadar MDA dalam darah rerata sebesar $5,86 \mu \mathrm{mol} / \mathrm{LA}$. Terdapat hubungan positif yang signifikan antara kadar timbal dengan kadar MDA dalam darah petugas di SPBU Jln. Monjali, SPBU Jln. Magelang dan SPBU Jln.Adjisucipto.

Petugas SPBU hendaknya mengonsumsi makanan yang mengandung vitamin E seperti kacang- kacangan untuk mengurangi dampak timbal di dalam tubuh yang dapat menyebabkan stres oksidatif dan penggunaan APD selama bekerja harus selalu diperhatikan. Manager SPBU supaya melakukan monitoring ling- kungan kerja terhadap kualitas udara khususnya timbal dan mengadakan pemeriksaan kesehatan bagi pekerja secara berkala dan pemantauan penggunaan APD bagi pekerja. 


\begin{abstract}
Abstrak
Tujuan: Penelitian ini bertujuan untuk mengetahui pengaruh kadar timbal dengan stress oksidatif pada petugas SPBU di daerah Sleman melalui pengukuran kadar malondialdehid (MDA). Metode: Penelitian ini adalah penelitian observasional analitik yang melibatkan petugas stasiun pengisian bahan bakar umum (SPBU) sebanyak 43 orang. Kadar timbal dalam darah diukur dengan metode spektrofotometer serapan atom (SSA). Kadar MDA serum diukur dengan metode TBRs. Hasil: Penelitian ini menemukan rerata kadar timbal dalam darah petugas SPBU sebesar 62,174 $\mu \mathrm{g} / \mathrm{L}$. Kadar MDA serum diperoleh rerata 5,86 $\mu \mathrm{mol} / \mathrm{L}$. Hasil uji statistik dengan menggunakan pearson correlation menunjukkan ada pengaruh yang signifikan antara kadar timbal dalam darah dengan kadar MDA $(p=0,000)$ dengan kekuatan hubungan sangat kuat $(r=0,8432)$. Simpulan: Petugas SPBU rentan terkena paparan timbal, sehingga perlu pencegahan agar kondisi kesehatan tidak memburuk dengan penggunaan alat pelindung diri (APD) yang benar, pola hidup sehat, dan melakukan medical check-up rutin.
\end{abstract}

Kata Kunci: kadar timbal darah; malondialdehid; petugas SPBU

\section{PUSTAKA}

1. Al-Fartosy AJ, Awad NA, Shanan SK. Biochemical correlation between some heavy metals, malondialdehyde and total antioxidant capacity in blood of gasoline station workers. International Research Journal of Environmental Sciences. 2014;3(9):56-60.

2. Lubis B, Rosdiana N, Nafianti S, Rasyianti O, Panjaitan FM. Hubungan keracunan timbal dengan anemia defisiensi besi pada anak. CDK-200. 2013;40(1):17-21

3. Kim J, Lee Y, Yang M. Environmental exposure to lead $(\mathrm{Pb})$ and variations in its susceptibility. Journal of Environmental Science and Health, Part C. 2014 Apr 3;32(2):159-85

4. Ati PW, Murbawani EA. Hubungan kecukupan asupan zat besi dan kadar timbal darah dengan kadar hemoglobin anak jalanan usia kurang dari 8 tahun di kawasan Pasar Johar Semarang (Doctoral dissertation, Diponegoro University).

5. Gusnita D. Pencemaran logam berat timbal (Pb) di udara dan upaya penghapusan bensin bertimbal. Berita Dirgantara. 2012;13(3).

6. Kawatu P. Analisis Kadar Timbal Darah dan Penyakit Hipertensi pada Petugas Stasiun Pengisian Bahan Bakar Umum di Kota Manado. Chemistry Progress. 2009;2(2).

7. Muliyadi M. Paparan timbal udara terhadap timbal darah, hemoglobin, cystatin c serum pekerja pengecatan mobil. Jurnal Kesehatan Masyarakat. 2015 Sep 11;11(1):87-95.

8. Tayrab E, Abdelrahman N, Tirba AK. Blood lead level among fuel station workers at Khartoum city. American Journal of Research Communication. 2014;2(6).

9. Laila NN, Shofwati I. Kadar timbal darah dan keluhan kesehatan pada operator wanita SPBU. Jurnal Kesehatan Reproduksi. 2013;4(1 Apr):41-9

10. Rosyidah H, Djannah SN. Hubungan antara kadar pb dalam darah dengan kejadian hipertensi pada operator SPBU di kota Yogyakarta. Jurnal Kesehatan Masyarakat (Journal of Public Health). 2013 Apr 13;4(2).

11. Ercal N, Gurer-Orhan H, Aykin-Burns N. Toxic metals and oxidative stress part I: mechanisms involved in metal-induced oxidative damage. Current topics in medicinal chemistry. $2001 \mathrm{Dec}$ 1;1(6):529-39.

12. Farmand F, Ehdaie A, Roberts CK, Sindhu RK. Lead-induced dysregulation of superoxide dismutases, catalase, glutathione peroxidase, and guanylate cyclase. Environmental Research. 2005 May 1;98(1):33-9.

13. Miyamoto, S., Alves, A., Noguire, L., Helen ,M., Di Mascio, P. Evaluation of Malondialdehyde Levels. Oxidative Stress in Aquatic Ecosystems. Blackwell Publishing Ltd. United Kingdom. 2012.

14. Valko M, Rhodes C, Moncol J, Izakovic MM, Mazur M. Free radicals, metals and antioxidants in oxidative stress-induced cancer. Chemico-

15. Ściskalska M, Zalewska M, Grzelak A, Milnerowicz $\mathrm{H}$. The influence of the occupational exposure to heavy metals and tobacco smoke on the selected oxidative stress markers in smelters. Biological trace element research. 2014 Jun 1;159(1-3):59-68.

16. Flora SJ, Mittal M, Mehta A. Heavy metal induced oxidative stress \& its possible reversal by chelation therapy. Indian Journal of Medical Research. 2008 Oct 1;128(4):501.

17. Awad, N.A., Sanaa, K.S., Adnan, J.M.A. Effect of Lead Exposure on Malondialdehyde (MDA) Level and Some Biochemical Parameter in Workers of Gasoline Stations. Research Journal of Pharmaceutical, Biological and Chemical Sciences.Vol 5(6). 2015.

18. Mutlu-Türkoğlu Ü, I lhan E, Öztezcan S, Kuru A, Aykaç-Toker G, Uysal M. Age-related increases in plasma malondialdehyde and protein carbonyl levels and lymphocyte DNA damage in elderly subjects. Clinical biochemistry. 2003 Jul 1;36(5):397-400.

19. Poljšak B, Dahmane R. Free radicals and extrinsic skin aging. Dermatology research and practice. 2012;2012.

20. Mouhamed DH, Ezzaher A, Neffati F, Douki W, Gaha L, Najjar MF. Study of a marker of oxidative stress in smokers: The malondialdehyde. Immuno-Analyse \& Biologie Specialisee. 2012 Aug 1;27(4):153-8.

21. Kusumawardhani AD. Faktor risiko yang berhubungan dengan kadar hemoglobin dan malondialdehid pada petugas parkir yang terpapar karbon monoksida di swalayan Surakarta. Jurnal Kesehatan Masyarakat (e-Journal). 2015 Mar 2;3(1):305-17.

22. Kumari Suchetha N.,Damodara Gowda K.M., Sukesh. N., Madhu L.N., Kathyayani.Effect of yoga therapy on body mass index and oxidative status. 
Nitte University Journal of Health Science. No. 1- 3. 2011.

23. Yesilbursa D, Serdar Z, Serdar A, Sarac M, Coskun $S$, Jale C. Lipid peroxides in obese patients and effects of weight loss with orlistat on lipid peroxides levels. International journal of obesity. 2005 Jan;29(1):142.

24. Higashi Y, Sasaki S, Nakagawa K, Kimura M, Noma K, Sasaki S, Hara K, Matsuura H, Goto C, Oshima T, Chayama K. Low body mass index is a risk factor forimpaired endothelium-dependent vasodilation in humans: role of nitric oxide and oxidative stress. Journal of the American College of Cardiology. 2003 Jul 16;42(2):256-63.

25. Khajehnasiri F, Mortazavi SB, Allameh A, Akhondzadeh S, Hashemi H. Total antioxidant capacity and malondialdehyde in depressive rotational shift workers. Journal of environmental and public health. 2013;2013.

26. Al-Attar AM. Antioxidant effect of vitamin $\mathrm{E}$ treatment on some heavy metals-induced renal and testicular injuries in male mice. Saudi journal of biological sciences. 2011 Jan 1;18(1):63-72. 
Berita Kedokteran Masyarakat, Volume 33 No. 4 Tahun 2017 